\title{
Effects of Alloying Elements on Flash Points of Lead
}

\author{
By Rokuro Kawabata,* Sunao Miyase** \\ and Masayoshi Tagaya**
}

\begin{abstract}
The measurement was made of the flash points, viz., the temperature at which lead and lead alloys suffer heavy corrosion and disintegration in a concentrated sulphuric acid solution. It was observed that the addition of alloying elements within the limit of solubility lowers the flash-point of lead alloys. Their effect may be classified as follows: With the increasing amount of the alloying element, the flash-point of lead alloys is

(1) lowered markedly: e.g. $\mathrm{Bi}, \mathrm{Sb}, \mathrm{Sn}, \mathrm{Zn}$

(2) lowered at first and then increased, but its temperature is lower than the flash-point of pure lead: e.g. Ag.

(3) lowered at first and then increased, resulting in a higher flash-point than that of pure lead: e.g. Ni, Cu, Te.

(Received September 10, 1963)
\end{abstract}

\section{Introduction}

Lead and lead alloys are widely used as a high resistant metal and alloy to sulphuric acid, but the measurement of corrosion resistance for sulphuric acid by the immersion test is usually time-consuming(1), and in most cases it is difficult to perform a long duration corrosion test. G. Lunge ${ }^{(2)}$ discovered that there is a great difference in the temperatures at which leads of varing purities suffer heavy corrosion and disintegration when they are heated in concentrated sulphuric acid solution, and this particular temperature is named the flash point of lead. This test procedure is proposed as a short duration test of corrosion re-

* Kimura Entetsu Chemical Machine Co., Ltd.

** Faculty of Engineering, Osaka University.

(1) M. Hanafusa \& R Kawabata; J. Japan Inst. Metals 21 (1957) 35.

(2) G. Lunge; Z anorg allg Chem., 5 (1892) 642. Trans. JIM sistance to sulphuric acid of lead.

The authors have measured the flash points of lead and leadalloys containing small quantities of various alloy elements in order to make clear the effect of alloy elements on the flash-point of lead.

\section{Experimental Method}

For the corrosion test, pure metals such as lead, bismuth, tin, zinc, antimony, tellurium, copper, nickel or silver, and lead alloys with one of these elements, $1 \mathrm{~cm}^{3}$ ( $1 \mathrm{~cm}$ cubic) in size, were placed in a $100 \mathrm{cc}$ concial beaker containing $50 \mathrm{cc}$ of concentrated sulphuric acid solution (Sp. Gr. 1.84) and a thermometer was inserted in the solution. The heating was carried out at the rate of $40^{\circ} \mathrm{C} / \mathrm{min}$. The temperature at which these metals and alloys were broken up or the resulting corrosion products were exfoliated and the solution was violently flashed was measured as 1964 Vol. 5 
the flash-point.

\section{Experimental Results}

\section{Flash-points of lead and lead alloys}

The flash-points of $99.9999 \% \mathrm{~Pb}$ (zone refined lead), $99.99 \% \mathrm{~Pb}$ (electrolytic lead whose impurities were measured by chemical analysis) and each lead alloy are shown in Table 1 and Figs. 1 8. The flash-points of the alloys of impure lead containing varying amounts of copper are shown in Table 2, and the flash-points of lead bismuth alloys containing copper, tellurium, nickel or silver are shown in Table 3 , and the flash-points of lead-antimony-copper and lead-bismuth-copper alloys are shown in Table 4.

The process of disintegration of each alloy is as follows.

\subsection{9\% Pb}

At about $160^{\circ} \mathrm{C}$, small bubbles began to appear on the surface of the lead, and the surface turned yellow. This was assumed due to the decomposition of sulphuric acid at a high temperature

$$
\mathrm{H}_{2} \mathrm{SO}_{4}=\mathrm{H}_{2} \mathrm{O}+\mathrm{SO}_{2}+\mathrm{O} \text {, }
$$

and the reaction between lead and oxygen in the nascent state formed yellow $\mathrm{PbO}$.

$$
\mathrm{Pb}+\mathrm{O}=\mathrm{PbO} \text {. }
$$

As the temperature reached about $200^{\circ} \mathrm{C}$, the yellow-

Table 1 Flash-Points of lead alloys.

\begin{tabular}{l|l|l|l|l|l|l|l|l}
\hline $\begin{array}{c}\text { Alloy } \\
\%\end{array}$ & $\mathrm{Bi}$ & $\mathrm{Sn}$ & $\mathrm{Zn}$ & $\mathrm{Sb}$ & $\mathrm{Te}$ & $\mathrm{Cu}$ & $\mathrm{Ni}$ & $\mathrm{Ag}$ \\
\hline $\begin{array}{c}\text { Electrolytic } \\
\text { lead }\end{array}$ & 305 & 305 & 305 & 305 & 305 & 305 & 305 & 305 \\
0.0015 & 303 & & & 280 & & & 304 & \\
0.003 & 303 & 295 & 280 & 275 & 264 & & 304 & \\
0.005 & 303 & & 280 & 260 & 258 & 304 & & 301 \\
0.006 & 303 & 295 & 280 & 253 & & 303 & 303 & \\
0.01 & 300 & & & & 274 & 303 & 305 & 300 \\
0.013 & 296 & 295 & 277 & 253 & & & 310 & \\
0.025 & 295 & 297 & 280 & 235 & & 303 & 314 & 265 \\
0.04 & 285 & 296 & & & 300 & 302 & 316 & \\
0.05 & 285 & 293 & 278 & 235 & & & & 265 \\
0.06 & & & & & 309 & 315 & 316 & \\
0.07 & 276 & & & & & & & 270 \\
0.08 & & & & & 315 & 315 & 316 & \\
0.10 & 160 & 293 & 272 & 225 & $>315$ & 315 & 316 & 275 \\
0.20 & 160 & 293 & 263 & 225 & & & & 276 \\
0.30 & & 260 & & & & & & 279 \\
0.40 & & 260 & & & & & & 284 \\
0.50 & & & & & & & & 284 \\
0.80 & & 235 & & & & & & 285 \\
1.00 & & & & & & & \\
10.0 & & & & & & & & \\
pure metal & 258 & 224 & 311 & 305 & 190 & $>320$ & $>320$ & 280 \\
\hline \hline
\end{tabular}

Table 3 Flash-Points of $\mathrm{Pb}-\mathrm{Bi}$ alloys, $\mathrm{Cu}$,

\begin{tabular}{|c|c|c|c|c|}
\hline $\begin{array}{c}\text { Quantity } \\
\text { of } \\
\text { addition }\end{array}$ & $0.08 \% \mathrm{Cu}$ & $0.082 \% \mathrm{Ni}$ & $0.08 \% \mathrm{Te}$ & $0.05 \% \mathrm{Ag}$ \\
\hline $\begin{array}{l}\mathrm{Pb}-0.05 \% \mathrm{Bi} \\
\mathrm{Pb}-0.1 \% \mathrm{Bi} \\
\mathrm{Pb}-0.2 \% \mathrm{Bi}\end{array}$ & $\begin{array}{l}312 \\
307 \\
294\end{array}$ & 309.5 & 305 & 260 \\
\hline
\end{tabular}
$\mathrm{Ni}$, Te or Ag.

Table 4 Flash-Points of $\mathrm{Pb}-\mathrm{Bi}-\mathrm{Cu}$ and $\mathrm{Pb}-\mathrm{Sb}-\mathrm{Cu}$ alloys.

\begin{tabular}{l|c}
\hline \hline Chemical composition & Flash point $\left({ }^{\circ} \mathrm{C}\right)$ \\
\hline $\mathrm{Pb}-0.04 \% \mathrm{Cu}-0.1 \% \mathrm{Bi}$ & 295 \\
$\mathrm{~Pb}-0.1 \% \mathrm{Cu}-0.1 \% \mathrm{Sb}$ & 307 \\
\hline
\end{tabular}

colored oxide film began to disappear, and the surface turned white perfectly at $240^{\circ} \mathrm{C}$. The reaction is considered as follows:

$$
\mathrm{PbO}+\mathrm{H}_{2} \mathrm{SO}_{4}=\mathrm{H}_{2} \mathrm{O}+\mathrm{PbSO}_{4} \text {. }
$$

As the temperature was further raised up to about $260^{\circ} \mathrm{C}$, the white-color lead sulphate film began to break up; and at $311^{\circ} \mathrm{C}$ it was seen to flash.

\subsection{9\% Pb}

The process was essentially the same as the above case of the high purity of $99.9999 \% \mathrm{~Pb}$, but the flash point was at $305^{\circ} \mathrm{C}$, slightly lower than in the above case.

\section{Pb-Bi alloys}

It was seen that the surface of lead alloys containing $0.1 \sim 0.2 \%$ bismuth turned yellow at $100 \sim 110^{\circ} \mathrm{C}$, and they were affected considerably at $140^{\circ} \mathrm{C}$. The alloys containing less than $0.04 \% \mathrm{Bi}$ were so much affected that they were exfoliated at $270 \sim 290^{\circ} \mathrm{C}$.

\section{$\mathbf{P b}-\mathrm{Sb}$ alloys}

The suface of $0.025 \sim 0.2 \% \mathrm{Sb}$ alloys turned greyishblack at $70^{\circ} \mathrm{C}$, besides which there were no particular changes up to about $220^{\circ} \mathrm{C}$.

\section{$\mathbf{P b}-$ Sn alloys}

At about $270^{\circ} \mathrm{C}$, the white-colored surface was so much affected that it was exfoliated. The lead-tin alloy containing less than $0.2 \%$ tin was not easily dissolved until it reached the flash-point.

\section{$\mathrm{Pb}-\mathrm{Zn}$ alloys}

The surface of $0.05 \sim 0.2 \% \mathrm{Zn}$ alloys turned black

\begin{tabular}{|c|c|c|c|c|c|c|}
\hline \multicolumn{6}{|c|}{ Chemical composision } & \multirow{2}{*}{ Flash point $\left({ }^{\circ} \mathrm{C}\right)$} \\
\hline $\mathrm{Pb} \%$ & $\mathrm{Sb}+\mathrm{Sn} \%$ & $\mathrm{Ag} \%$ & $\mathrm{Bi} \%$ & $\mathrm{Zn} \%$ & $\mathrm{Cu} \%$ & \\
\hline 99.96 & 0.008 & 0.001 & 0.03 & $\operatorname{tr}$ & $\operatorname{tr}$ & 250 \\
\hline 99.92 & 0.008 & 0.001 & 0.03 & $\operatorname{tr}$ & 0.04 & 302 \\
\hline 99.9 & 0.008 & 0.001 & 0.03 & $\operatorname{tr}$ & 0.06 & 304 \\
\hline 99.8 & 0.008 & 0.001 & 0.03 & $\operatorname{tr}$ & 0.08 & 306 \\
\hline 99.8 & 0.008 & 0.001 & 0.03 & tr & 0.1 & 308 \\
\hline
\end{tabular}
at about $50^{\circ} \mathrm{C}$ and yellow at $260^{\circ} \mathrm{C}$ with a violent

Table 2 Flash-Point of $\mathrm{Pb}-\mathrm{Cu}$ alloys. 




Fig. 1 Effect of bismuth content on the flash point of lead-bismuth alloy.



Fig. 2 Effect of tin content of the flash point of lead-tin alloy.



Fig. 3 Effect of tin content on the flash point of lead-zine alloy.

reaction. $5 \% \mathrm{Zn}$ alloy began to produce bubbles at $160^{\circ} \mathrm{C}$ and to dissolve a little at $285^{\circ} \mathrm{C}$. It flashed at $299^{\circ} \mathrm{C}$.

\section{Pb-Ag alloys}

At $30^{\circ} \mathrm{C}$, the surface of these alloys turned black. The occurrence of bubbles decreased as compared with the other alloys.

\section{$\mathbf{P b}-\mathrm{Cu}$ alloys}

The surface of these alloys turned black at about $50^{\circ} \mathrm{C}$ and turned white with sporadic bubbles at $250 \sim$ $260^{\circ} \mathrm{C}$. The specimens did not suffer disintegration

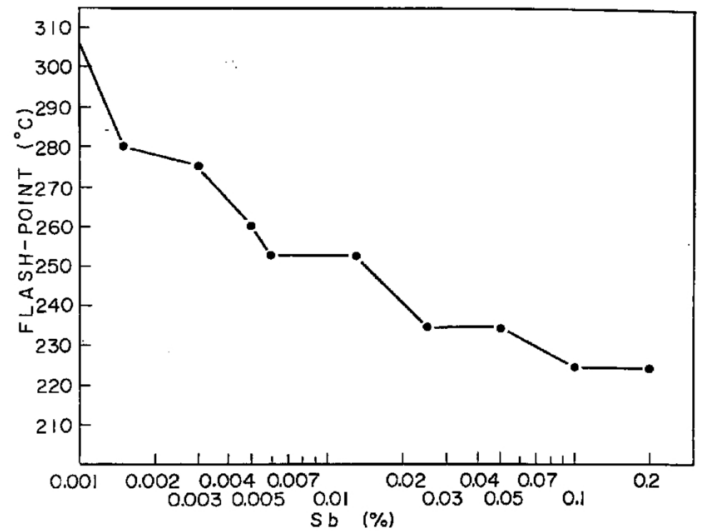

Fig. 4 Effect of antimony content on the fiash point of lead-antimony alloy.

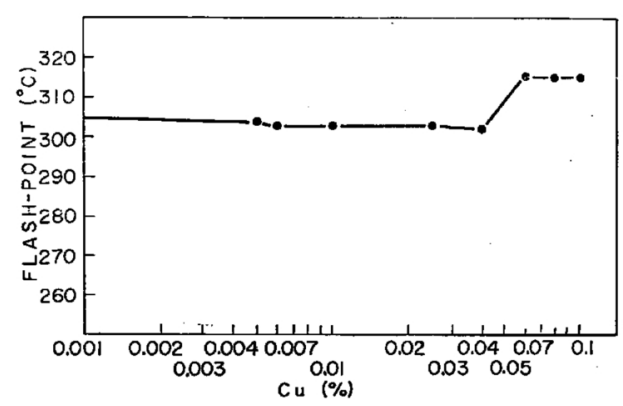

Fig. 5 Effect of copper content on the flash point of lead-copper alloy.



Fig. 6 Effect of tellurium content on the flash point of lead-tellurium alloy.

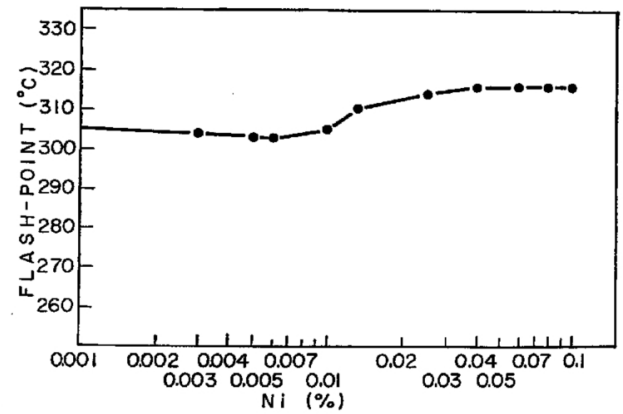

Fig. 7 Effect of nickel content on the flash point of lead-nickel alloy. 




Fig. 8. Effect of silver content on the flash point of leadsilver alloy.

between 302 and $315^{\circ} \mathrm{C}$.

\section{$\mathrm{Pb}$-Te alloys}

$0.03 \sim 0.013 \% \mathrm{Te}$ alloys began to generate small bubbles at about $160^{\circ} \mathrm{C}$, and the bubbles appeared very briskly at about $220^{\circ} \mathrm{C}$. At the flash-point temperature, the specimen's surface was corroded, and the solution turned white.

In the case of $0.04 \%$ Te alloy, bubbles started sporadically from about $260^{\circ} \mathrm{C}$, and a rapid reaction took place at $300^{\circ} \mathrm{C}$. For $0.08 \%$ Te alloy, the sulphuric acid only became slightly whitish and the specimens remained practically unaffected. $0.1 \% \mathrm{Te}$ alloy had almost no change on the surface at $315^{\circ} \mathrm{C}$ and sulphuric acid remained colorless.

\section{Pb-Ni alloys}

The solution which contain lead alloys containing less than $0.04 \%$ nickel showed light-brown color from $150^{\circ} \mathrm{C}$, and small bubbles started to appear at about $160^{\circ} \mathrm{C}$. The lead alloys with more than $0.06 \%$ nickel showed practically no change at the outset, and bubbles began to appear from the lower part at about $230^{\circ} \mathrm{C}$. At about $255^{\circ} \mathrm{C}$ small bubbles appeared over the lower part, and at $310^{\circ} \mathrm{C}$ bubbles were produced profusely, but the solution remained transparent up to $315^{\circ} \mathrm{C}$. The specimens retained their shape until the flash-point.

\section{$\mathbf{P b}-\mathrm{Cu}-\mathrm{Bi}$ alloys}

The surface of $\mathrm{Pb}-\mathrm{Cu}-\mathrm{Bi}$ alloys turned black at $200^{\circ} \mathrm{C}$, and the black surface film was exfoliated a little at $268 \sim 275^{\circ} \mathrm{C}$.

\section{$\mathbf{P b}$-Te-Bi alloys}

$\mathrm{Pb}-0.082 \% \mathrm{Te}-0.1 \% \mathrm{Bi}$ alloy started bubbling at about $190^{\circ} \mathrm{C}$ and produced bubbles profusely at $260^{\circ} \mathrm{C}$.

\section{Pb-Ag-Bi alloys}

For this alloy, bubbles began to come out at about $200^{\circ} \mathrm{C}$, and the specimen was completely disintegrated at $260^{\circ} \mathrm{C}$.

\section{Pb-Ni-Bi alloys}

This alloy produced bubbles at about $190^{\circ} \mathrm{C}$. As the temperature rose up to $300^{\circ} \mathrm{C}$, the bubbles came out profusely.

\section{$\mathbf{P b - S b - C u}$ alloys}

The surface of $\mathrm{Pb}-0.1 \% \mathrm{Sb}-0.1 \% \mathrm{Cu}$ alloy turned black at $80^{\circ} \mathrm{C}$, and the solution turned light-brown at $160^{\circ} \mathrm{C}$. From about $270^{\circ} \mathrm{C}$, bubbles came out profusely, and the surface began to be decomposed at $286^{\circ} \mathrm{C}$. At $307^{\circ} \mathrm{C}$, it was corroded violently.

\section{Flash-points of individual alloy element}

The flash-points of the pure metals, which were alloyed with lead at the experiment described in $3 \sim 1$ were measured. The results obtained are shown in Table 1.

\section{Bismuth}

At $120^{\circ} \mathrm{C}$, the specimen's surface turned black. The specimen began to dissolve at $252^{\circ} \mathrm{C}$ and broke up at $258^{\circ} \mathrm{C}$.

Tin

At $120^{\circ} \mathrm{C}$, the specimen's surface turned white. At $140^{\circ} \mathrm{C}$ bubbles began to come out, and the specimen was broken up at $224^{\circ} \mathrm{C}$.

\section{Zinc}

Small bubbles began to generate on the specimen's surface at about $90^{\circ} \mathrm{C}$, and the solution turned lightbrown. From $190^{\circ} \mathrm{C}$, bubbles generated profusely, while the color of the solution grew to deeper brown. At $300^{\circ} \mathrm{C}$, this condition continued. At $311^{\circ} \mathrm{C}$, the flash took place.

\section{Antimony}

At about $130^{\circ} \mathrm{C}$, small bubbles began to generate. At $180^{\circ} \mathrm{C}$, the surface of the specimen turned black, and bubbles were seen to generate violently at $220^{\circ} \mathrm{C}$. At $260^{\circ} \mathrm{C}$ bubbles become more and more profuse. At $305^{\circ} \mathrm{C}$, the specimens was disintegrated into antimony sulphate.

\section{Tellurium}

At room temperature, the surface of tellurium assumed pink color, and at $110^{\circ} \mathrm{C}$ the whole sulphuric acid turned crimson. At about $135^{\circ} \mathrm{C}$, small bubbles generate so profusely that the specimens became invisible.

From $180^{\circ} \mathrm{C}$, large bubbles began to generate briskly and the break-up took place at $190^{\circ} \mathrm{C}$.

\section{Copper}

When copper was heated in sulphuric acid, the following reaction took place:

$$
\begin{gathered}
\mathrm{H}_{2} \mathrm{SO}_{4}=\mathrm{H}_{2} \mathrm{O}+\mathrm{O}+\mathrm{SO}_{2} \\
\mathrm{Cu}+\mathrm{O}=\mathrm{CuO}
\end{gathered}
$$

( $\mathrm{CuO}$ is black and it's melting point is $1,260^{\circ} \mathrm{C}$ ). Hence

$$
\mathrm{CuO}+\mathrm{H}_{2} \mathrm{SO}_{4}=\mathrm{CuSO}_{4}+\mathrm{H}_{2} \mathrm{O}
$$

and copper sulphate was thus produced. As the temperature was raised rapidly, the black-colored $\mathrm{CuO}$ appeared distinctly at $130^{\circ} \mathrm{C}$, and white-colored $\mathrm{CuSO}_{4}$ appeared clearly at $170^{\circ} \mathrm{C}$. At $250^{\circ} \mathrm{C}$, the solution presented light-green color and bioled at $320^{\circ} \mathrm{C}$. However, the copper specimen was not broken up.

\section{Nickel}

No change was noted to be occurred by heating, except the formation of a few bubbles at elevated temperatures.

The sulphuric acid containing nickel boiled nearly up to $320^{\circ} \mathrm{C}$, but it retained its original shape.

\section{Silver}


Between 160 and $250^{\circ} \mathrm{C}$, the only change was the appearance of bubbles. More bubbles generate between 270 and $280^{\circ} \mathrm{C}$ was seen to be the flash-point. As the temperature was further raised, silver was completely dissolved at $310^{\circ} \mathrm{C}$.

However, the specimens did not break up so abruptly as lead and its dissolution occurred gradually.

\section{Consideration}

When an extermely small amount of a metallic element (less than $0.03 \%$ ) is added to lead, the flashpoint of lead is lowered irrespective of the kind of the metallic element.

As shown in Figs. 1 8, however, the effect of addition of the alloying element in the flash-point of lead may be classified as follows:

1. The flash-point lowers markedly.

2. The flash-point lowers at first and then rises, but it is lower than the flash-point of pure lead.

3. The flash-point lowers at first and then rises to be higher than that of pure lead.

These various processes are determined by the kinds of alloying elements.

(1) The fiash-point of lead alloys containing low flash-point metal

When the low flash-point metal was alloyed to lead, the flash-point lowered markedly. This applies to the lead alloys with bismuth, antimony or tin. If a low flash-point metal is alloyed beyond the limit of the solid solubility and produces $\beta$ phases of high flashpoint, the flash-point of alloy rises. This applies to the lead alloys with tellurium.

(2) The flash-points of lead alloys containing medium fiash-point metal

The alloying metals which are added within the range of solid solubility lower the flash-point, but an addition in excess of the solid solubility raises the flashpoint.

As the amount of addition increases, the flashpoint rises, but it does not rise so much higher than that of alloying metal. This applies to the lead alloys with silver.

\section{(3) The flash-points of lead alloys containing high flash-point metal}

When a high flash-point metal is alloyed to lead and is segregated at the grain boundary, the flash-point of this lead alloy rises higher than that of pure lead. This applies to the lead alloys with nickel. If a high flash-point metal exists as segregated particles in the crystal, the crystal grains of lead become extremely fine and the grain boundary per unit area is greatly lengthened, resulting in dispersion of the impurities at the grain boundary, and consequently the flash-point of this lead alloy becomes high. This applies to the lead alloys with copper. There is a case in which the lead alloys with a high flash-point metal reveal the low flash-point. This applies to the lead alloys with zinc.

The effects of a single alloying element on the flash- points of lead, as described above, may be summarized as follows. When a metal is added to lead within the limit of solid solubility, the flash-point of lead will lower, irrespective of the kind of the added metal.

When a metal is added beyond the limit of the solid solubility and begins to precipitate as $\beta$ phases, the flash-point of lead will be affected by the nature of $\beta$ phases or eutectic, provided that the metal is of low solubility.

In the case of a high solid solubility, even though the flash-point of the precipitated $\beta$ phases is high, the flash-point of this alloy is equal to that of the solid solution.

\section{(4) Effect of third element on the lead alloys of low flash-point}

The metal which tends to rise the flash-point of lead affects the lead alloy of low flash-point.

\section{(i) Effect of copper additions on lead-bismuth alloy}

According to the equilibrium diagrams of the leadbismuth, bismuth copper and lead-copper systems, bismuth has a high solid solubility to lead, but the solid solubility of the copper-bismuth and copper-lead systems is negligibly small. As for the ternary system of copper, lead and bismuth, when a small amount of bismuth is alloyed to lead, bismuth is dissolved in lead and the solid solution shows $a$ phase.

The solution may be considered the binary system of $\alpha$ phases and copper

Namely, as shown in Photo. 1, the copper added is located in the center of the crystal grains of lead,

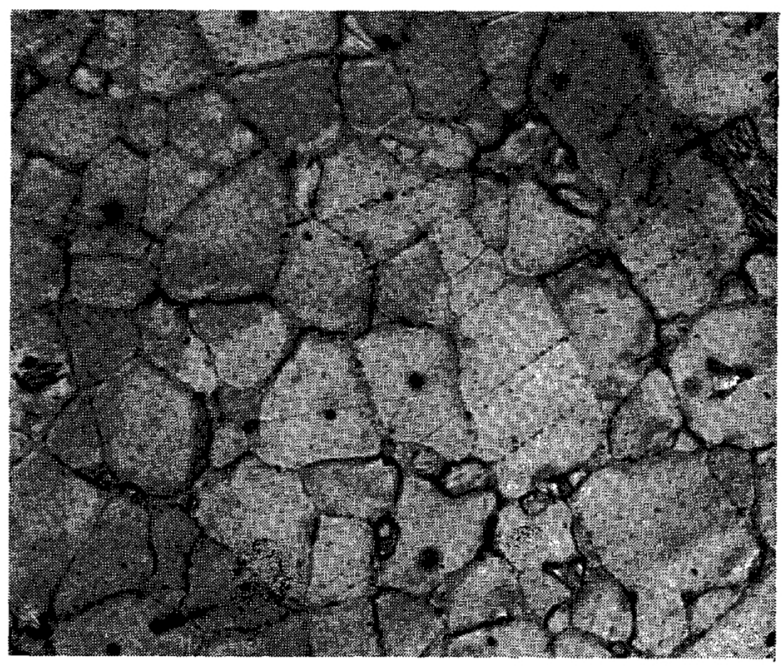

Photo. $1 \mathrm{~Pb}-0.06 \% \mathrm{Cu}$ alloy as cast.

$\times 200$

and makes them extremely fine, and thus the grain boundary is lengthened. In consequence, the concentration of bismuth in the solid solution an which is relatively high is reduced, and it is assumed that bismuth does not so much influence the flash-point of this alloy. The flash-point of this alloy is considered to be equal to that of lead-copper alloy.

Accordingly, the copper added is concentrated in the center of the grains of lead, and when this alloy is heated in sulphuric acid, the copper becomes black 
copper oxide and then turns to white copper sulphate. Copper sulphate with lead sulphate which is grown out of the matrix forms a film which wraps the specimen and gives a high flash-point.

\section{(ii) Effect of copper on lead-antimony alloy}

An extremely small amount of antimony lowers the flash-point of lead greatly. When copper is added to this lead-antimony alloy, a flash-point above $300^{\circ} \mathrm{C}$ is obtained as shown in Table 4. This result may be explained as follows. Since antimony-copper alloy has a higher melting point than lead, it crystallizes preferentially from molten alloy and acts as nucleus for crystallization of molten lead: It causes the grain refinement of lend-antimony-copper alloy. So the grain boundary increases, and excess antimony in the lead which does not consist nuclei gathers at the grain boundary. As a result, antimony is extremely dispersed.

(iii) Effect of tellurium on lead-bismuth alloy

The equilibrium diagram of the bismuth-tellurium. system bears a close resemblance to that of the leadtellurium system. It makes an intermediate phase having a high melting-point and this intermediate phase has also an exceedingly high flash-point. In contrast to the fact that the flash-points of tellurium and bismuth are $190^{\circ} \mathrm{C}$ and $258^{\circ} \mathrm{C}$ respectively, the flashs-point of a $50 \% \mathrm{Te}-50 \% \mathrm{Bi}$ alloy is higher than $315^{\circ} \mathrm{C}$, and is close to the boiling point of sulphuric acid, but the alloy does not break up at $315^{\circ} \mathrm{C}$.

As shown in Photo. 2. $\beta$ phase of lead and tellurium precipitats at the grain boundary of fine lead crystals. It is assumed that the ternary alloy of $\mathrm{Pb}-\mathrm{Te}-\mathrm{Bi}$ precipitates an intermediate phase $\mathrm{Te}-\mathrm{Bi}-\mathrm{Pb}$ at the grain boundary and then raises the flash-point.

(iv) Effect of nicked on a lead-bismuth alloy

According to the equilibrium diagrams of bismuthnickel, this alloy has a higher melting point than bismuth. The flash-point of $40 \%-\mathrm{Ni}-60 \% \mathrm{Bi}$ alloy is as high as $320^{\circ} \mathrm{C}$.

As shown in Photo. 3, $\beta$ phase of lead and nickel is found at the grain boundary of lead crystals.

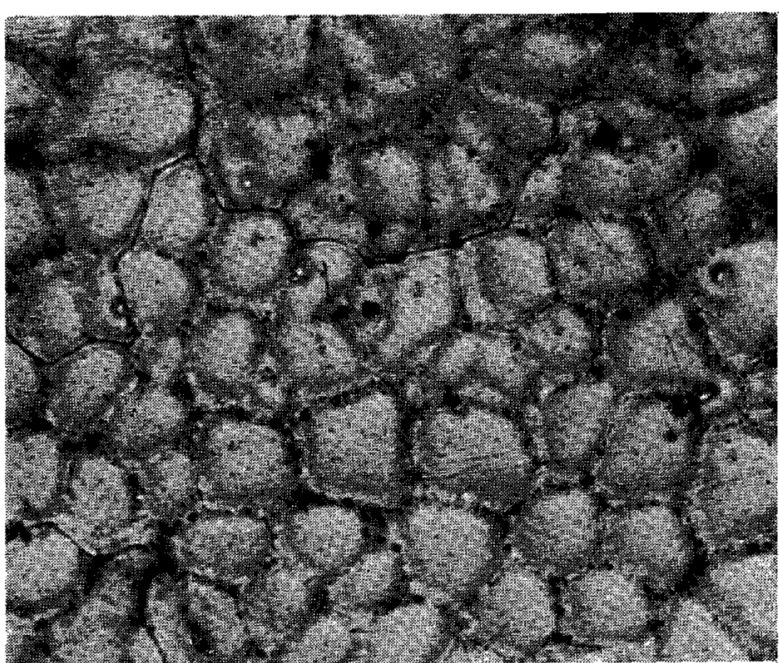

Photo. $2 \mathrm{~Pb}-0.06 \% \mathrm{Te}$ alloy as cast. $\times 200$



Photo. $3 \mathrm{~Pb}-0.07 \% \mathrm{Ni}$ alloy as cast. $\times 200$

It seems that the ternary phase of $\mathrm{Pb}-\mathrm{Ni}-\mathrm{Bi}$ of high flash-point, produced at the grain boundary is prevented from reducing the flash-point by the addition of bismuth. 